\title{
Pengaruh Kejelasan Sasaran Anggaran, Sistem Pelaporan dan Partisipasi Masyarakat Pada Akuntabilitas Pengelolaan Dana Desa
}

\author{
I Made Agus Suma Arta ${ }^{1}$ \\ Ni Ketut Rasmini ${ }^{2}$ \\ ${ }^{1,2}$ Fakultas Ekonomi dan Bisnis Universitas Udayana (Unud), Bali, Indonesia \\ e-mail: sumaarta8@gmail.com
}

\begin{abstract}
ABSTRAK
Penelitian ini bertujuan untuk mengetahui pengaruh dari kejelasan sasaran anggaran, sistem pelaporan, dan partisipasi masyarakat pada akuntabilitas pengelolaan dana desa di Kecamatan Seririt Kabupaten Buleleng. Sampel penelitian ini adalah 20 desa di Kecamatan Seririt dengan jumlah reponden sebanyak 80 orang. Metode penentuan sampel menggunakan metode sampel jenuh dan pengumpulan data dengan menggunakan kuesioner. Data dianalisis dengan menggunakan analisis Regresi Linier Berganda. Berdasarkan hasil penelitian ini menunjukkan bahwa kejelasan sasaran anggaran, sistem pelaporan, dan partisipasi masyarakat berpengaruh positif pada akuntabilitas pengelolaan dana desa. Hal ini menunjukkan bahwa semakin baik kejelasan sasaran anggaran, sistem pelaporan, dan partisipasi masyarakat maka akuntabilitas pengelolaan dana desa di Kecamatan Seririt Kabupaten Buleleng akan semakin baik.
\end{abstract}

Kata Kunci: kejelasan sasaran anggaran, sistem pelaporan, partisipasi masyarakat, akuntabilitas

\begin{abstract}
This study aims to determine the effect of the clarity of budget targets, reporting systems, and community participation in the accountability of village fund management in Seririt District, Buleleng Regency. The study sample was 20 villages in Seririt District with 80 respondents. The method of determining the sample uses the saturated sample method and data collection using a questionnaire. Data were analyzed using multiple linear regression analysis. Based on the results of this study indicate that the clarity of budget targets, reporting systems, and community participation has a positive effect on the accountability of village fund management. This shows that the better the clarity of budget targets, reporting systems, and community participation, the better accountability of village fund management in Seririt District, Buleleng Regency.
\end{abstract}

Keywords: clarity of budget targets, reporting systems, community participation, accountability

\section{PENDAHULUAN}

Perubahan pemerintahan Indonesia secara desentralisasi dalam otonomi daerah mengakibatkan perubahan pada pola hubungan antara pemerintah pusat dan pemerintah daerah. Pola perubahan hubungan tersebut adalah perubahan wewenang dan tanggung jawab pemerintah di tingkat pusat maupun daerah. Namun demikian terdapat kewenangan yang tidak dapat di desentralisaikan dalam 
I Made Agus Suma Arta dan Ni Ketut Rasmini. Pengaruh...

otonomi daerah, yaitu urusan politik luar negeri, pertahanan, keamanan, moneter dan fiskal, hukum, serta agama (Syamsudin, 2007:328) dalam (Astuty, 2013).

Konsep desentralisasi dalam Undang-undang Nomor 32 Tahun 2004 tentang Pemerintah Daerah telah menunjuk tiga pola otonomi (Astuty, 2013). Pertama, otonomi provinsi sebagai otonomi terbatas. Kedua, otonomi kabupatan/kota sebagai otonomi luas. Ketiga, otonomi desa merupakan otonomi yang asli, bulat dan utuh serta bukan merupakan pemberian dari pemerintah sebaliknya pemerintah berkewajiban menghormati otonomi asli yang dimiliki oleh desa tersebut.

Menurut Undang-undang No. 6 Tahun 2014, desa adalah kesatuan masyarakat hukum yang memiliki batas wilayah yang berwenang untuk mengatur dan mengurus urusan pemerintahan, kepentingan masyarakat setempat berdasarkan prakarsa masyarakat, hak asal usul, dan/atau hak tradisional yang diakui dan dihormati dalam sistem pemerintahan Negara Kesatuan Republik Indonesia. Desa berhak untuk mengatur dan mengurus pemerintahannya sendiri untuk memajukan prekonomian desa, membangun desanya masing-masing dan meningkatkan taraf hidup masyarakatnya.

Pemerintahan desa adalah penyelenggara urusan pemerintah dan kepentingan masayarakat setempat dalam sistem pemerintahan Negara Kesatuan Republik Indonesia. Pemerintah desa adalah kepala desa dan dalam menjalankan pemerintahan desa, akan dibantu oleh badan permusyawaratan desa. Badan permusyawaratan desa atau yang sering disebut dengan nama lain adalah lembaga yang melaksanakan fungsi pemerintahan yang anggotanya merupakan wakil dari 
penduduk desa berdasarkan keterwakilan wilayah ditetapkan secara demokratis. Pada saat penyusunan kebijakan ataupun peraturan desa, kepala desa dibantu oleh badan permusyawaratan desa akan melakukan musyawarah desa.

Musyawarah desa menurut undang-undang No. 6 Tahun 2014 menyatakan bahwa musyawarah desa atau yang disebut dengan nama lain adalah musyawarah antara badan permusyawaratan desa, pemerintah desa, dan unsur masyarakat yang diselenggarakan oleh badan permusyawaratan desa untuk menyepakati hal yang bersifat strategis. Musyawarah desa biasanya diadakan paling kurang 1 kali dalam setahun. Bisanya didalam musyawarah desa semua golongan yang ada di masyarkat akan ikut terlibat untuk menyusun kebijakan-kebijakan yang akan dilakukan oleh pemerintah desa untuk meningkatkan perekonomian dan meningkatkan taraf hidup masyarakat yang ada di desa tersebut. Melalui permusyawaratan desa, diharapkan dapat menghasilkan kebijakan-kebijakan yang diperlukan oleh masyarakat desa itu sendiri.

Kebijakan-kebijakan hasil dari musyawarah desa akan menjadi rencana kerja desa (RKP). Pendanaan RKP desa bersumber dari APBDesa. APBDesa adalah peraturan desa yang memuat sumber-sumber penerimaan dan alokasi pengeluaran desa dalam kurun waktu satu tahun. APBDesa terdiri dari pedapatan, belanja desa dan pembiayaan. Dalam Permendagri No. 113 Tahun 2014, pendapatan desa berasal dari pendapatan asli desa, pendapatan transfer yang didalamnya terdapat dana desa, dan pendapatan lain-lain.

Dana desa adalah dana APBN yang diperuntukkan bagi desa yang ditransfer melalui APBD Kabupaten/Kota dan diprioritaskan untuk pelaksanaan 
I Made Agus Suma Arta dan Ni Ketut Rasmini. Pengaruh...

pembangunan dan pemberdayaan masyarakat. Adapun tujuan dari pemberian dana adalah untuk meningkatkan pelayanan publik desa, menuntaskan kemiskinan, memajukan perekonomian desa, mengatasi kesenjangan pembangunan antar desa dan memperkuat masyarakat desa sebagai subjek pembangunan. Pada pemerintahan presiden Jokowi, pengalokasian dana desa dari mulai tahun 2015 sampai 2017 terus mengalami peningkatan yang signifikan.

Pada tahun 2015 alokasi dana desa sebesar Rp20,76 triliun, kemudian tahun 2016 sebesar Rp46,9 triliun dan untuk tahun 2017 alokasi dana desa sebesar Rp60 triliun. Dimana tiap-tiap desa yang ada di Indonesia akan mendapatkan alokasi dana desa sebesar Rp800.000.000,00 (DJPK Kemenkeu, 2017). Alokasi dana desa adalah anggaran keuangan yang diberikan pemerintah kepada desa, yangmana sumbernya berasal dari bagi hasil pajak daerah serta dari dana perimbangan keuangan pusat dan daerah yang diterima oleh kabupaten.

Provinsi Bali merupakan salah satu provinsi yang menerima dana desa. Pengalokasian dana desa untuk provinsi Bali dibagikan kepada 8 kabupaten dan 1 kota madya. Jumlah desa keseluruhan di Bali yaitu sebanyak 636 desa dan masing-masing memperoleh alokasi dana sebesar Rp720.442.000,00. Rincian dari dana desa untuk Provinsi Bali tahun 2017 dapat dilihat pada Tabel 1. 
Tabel 1.

Daftar Rincian Dana Desa untuk Provinsi Bali Tahun 2017 (dalam ribuan rupiah)

\begin{tabular}{clccccc}
\hline No. & $\begin{array}{c}\text { Nama } \\
\text { Kabupaten/Kota }\end{array}$ & $\begin{array}{c}\text { Jumlah } \\
\text { Desa }\end{array}$ & $\begin{array}{c}\text { Alokasi Dasar } \\
\text { Pesa }\end{array}$ & $\begin{array}{c}\text { Alokasi } \\
\text { Per } \\
\text { Kab/Kota }\end{array}$ & Jumlah \\
\hline 1. & Badung & 46 & 720.442 & 33.140 & 7.175 & 40.315 \\
2. & Bangli & 68 & 720.442 & 48.990 & 6.793 & 55.783 \\
3. & Buleleng & 129 & 720.442 & 92.937 & 12.923 & 105.860 \\
4. & Gianyar & 64 & 720.442 & 46.108 & 9.645 & 55.753 \\
5. & Jembrana & 41 & 720.442 & 29.538 & 6.937 & 36.475 \\
6. & Karangasem & 75 & 720.442 & 54.033 & 9.649 & 63.682 \\
7. & Klungkung & 53 & 720.442 & 38.183 & 6.356 & 44.540 \\
8. & Tabanan & 133 & 720.442 & 95.818 & 10.599 & 106.417 \\
9. & Denpasar & 27 & 720.442 & 19.451 & 8.976 & 28.428 \\
\hline \multicolumn{5}{l}{ Sumber: Kementrian Desa, Pembangunan Daerah Tertinggal dan Trasmigrasi RI, 2018 }
\end{tabular}

Rincian dana desa untuk provinsi bali pada tahun 2017 menyebutkan bahwa Kabupaten Buleleng merupakan kabupaten yang mendapatkan dana desa terbesar kedua di Bali sejumlah Rp105.860.971.000,00. Disamping itu juga Kabupaten Buleleng merupakan kabupaten terluas di Bali yang luasnya 1.366 $\mathrm{Km}^{2}$. Kabupaten Buleleng memiliki 9 kecamatan yang membentang dari timur sampai barat pulau Bali.

Sembilan Kecamatan yang ada di Kabupaten Buleleng antara lain Kecamatan Tejakula, Kubutambahan, Sawan, Buleleng, Sukasada, Banjar, Seririt, Busung Biu, dan Gerokgak. Jumlah desa keseluruhan yang ada di Kabupaten Buleleng sebanyak 129 desa. Adapun rincian dari dana desa untuk Kabupaten Buleleng Tahun 2017 dapat dilihat pada tabel 2. 
Tabel 2.

Daftar Rincian Dana Desa untuk Kabupaten Buleleng Tahun 2017

\begin{tabular}{llccccccc}
\hline No. & $\begin{array}{c}\text { Nama } \\
\text { Kecamatan }\end{array}$ & $\begin{array}{c}\text { Jumlah } \\
\text { Desa }\end{array}$ & JP & JPM & LW & IKG & $\begin{array}{c}\text { Dana Desa } \\
\text { (Rp) }\end{array}$ & \% \\
\hline 1. & Seririt & 20 & 65.133 & 5.679 & 110 & 604 & 16.147 .676 .279 & 15,25 \\
2. & Banjar & 17 & 71.440 & 5.032 & 173 & 491 & 13.896 .779 .680 & 13,13 \\
3. & Busung Biu & 15 & 40.530 & 2.715 & 197 & 484 & 12.030 .341 .624 & 11,36 \\
4. & Gerokgak & 14 & 82.640 & 7.181 & 357 & 383 & 12.109 .781 .218 & 11,44 \\
5. & Sukasada & 14 & 69.272 & 4.249 & 166 & 432 & 11.568 .665 .124 & 10,93 \\
6. & Sawan & 14 & 60.030 & 3.635 & 93 & 384 & 11.325 .906 .119 & 10,70 \\
7. & Kubutambahan & 13 & 55.120 & 5.252 & 118 & 417 & 10.815 .847 .972 & 10,22 \\
8. & Buleleng & 12 & 50.940 & 2.477 & 28 & 367 & 9.621 .982 .646 & 9,09 \\
9. & Tejakula & 10 & 54.070 & 4.142 & 98 & 259 & 8.343 .990 .333 & 7,88 \\
\hline
\end{tabular}

Sumber: Kementrian Desa, Pembangunan Daerah Tertinggal dan Trasmigrasi Republik Indonesia, 2018

Keterangan:

- JP = Jumlah Penduduk.

- JPM = Jumlah Penduduk Miskin.

- LW = Luas Wilayah.

- IKG = Indeks Kesulitan Geografis.

Tabel 2 menerangkan pembagian dana desa di Kabupaten buleleng. Pengalokasian dana desa untuk tiap desa yang berada di masing-masing kecamatan berbeda disebabkan oleh beberapa faktor, yaitu jumlah penduduk, angka kemiskinan, luas wilayah dan tingkat kesulitan geografis. Prioritas penggunaan dana desa dialokasikan untuk mencapai tujuan pembangunan desa, meningkatkan kesejahteraan masyarakat desa, kualitas hidup dan penanggulangan kemiskinan. Selain itu salah satu kecamatan di Kabupaten Buleleng yaitu kecamatan Seririt menerima dana desa terbanyak yaitu sebesar Rp16.147.676,278 yang merupakan 15,25\% dari jumlah dana desa di Kabupaten Buleleng.

Kecamatan Seririt terdiri dari 20 desa dan 1 kelurahan. Dengan besarnya dana desa yang diberikan oleh pemerintah, diharapkan dana tersebut dapat dipergunakan untuk meningkatkan taraf hidup masyarakat di Kecamatan Seririt. Kecamatan Seririt menempati posisi kedua yang memiliki jumlah penduduk miskin tertinggi setelah Kecamatan Gerokgak. Disamping itu juga Kecamatan 
Seririt memiliki tingkat kesulitan geografis tertinggi dibandingkan dengan Kecamatan-Kecamatan lain di Kabupaten Buleleng. Indeks kesulitan geografis meliputi ketersediaan prasarana pelayanan dasar, kondisi infrastruktur dan aksesibilitas/transportasi (Kemendesa, 2018).

Besarnya pendapatan yang diterima desa menimbulkan kekawatiran mengenai kesiapan desa dalam mengelola dana tersebut. Terbukti dengan adanya kasus korupsi dana desa di desa Satra yang berada di Kabupaten Kelungkung. Perbekel Desa Satra menggunkan dana APBDesa sebesar Rp94 juta untuk memperkaya dirinya sendiri (bali.tribunnews.com). Maka dari itu diperlukan akuntabilitas dalam mengelola dana desa. Akuntabilitas dimaksudkan untuk memastikan kepercayaan masyarakat pada pemerintah serta menjembatani kesenjangan antara masyarakat dengan pemerintah (Aucoin dan Heintzmen, 2000) dalam (Mahayani, 2017). Dalam membangun kepercayaan tersebut, organisasi sektor publik harus membangun akuntabilitasnya atas dasar harapan para principal, bukan demi kepentingan agen semata (Randa, 2014). Akuntabilitas juga dimaksudkan sebagai mekanisme pertanggungjwaban atas kinerja pejabat publik yang dijabarkan melalui tindakan yang sesuai dengan peraturan dan prilaku etis (Scott, 2000: Mulgan, 2003) dalam (Mahayani, 2017).

Akuntabilitas bukan sekedar pertanggungjawaban keuangan secara formal suatu organisasi, tetapi merupakan pertanggungjawaban yang meliputi kepatuhan pada peraturan, lingkungan organisasi, masyarakat dan pemerintah (Patton, 1992) dalam (Mahayani, 2017). Selain itu juga akuntabilitas merupakan salah satu upaya untuk mewujudkan good governance khususnya pada instansi pemerintah. 
I Made Agus Suma Arta dan Ni Ketut Rasmini. Pengaruh...

Perwujudan akuntabilitas dapat dilakukan dengan menerapkan prinsip-prinsipnya. Tujuan dari penerapan prinsip-prinsip tersebut agar pemerintah dapat meningkatkan kinerja secara efektif dan transparan didukung dengan komitmen yang kuat untuk melaksanakannya (Astuty, 2013).

Pemerintah selaku pengelola dana publik agar dapat memenuhi akuntabilitas harus memperhatikan beberapa hal antara lain: anggaran, pengendalian akuntansi, dan sistem pelaporan (Suratmi, 2014). Anggaran adalah suatu bentuk rencana yang disajikan secara kuantitatif dalam satuan uang dan memiliki jangka waktu tertentu. Salah satu hal terpenting yang harus diperhatikan dalam suatu penganggaran yaitu kejelasan sasaran anggaran. Dengan adanya kejelasan sasaran anggaran, maka target-target sasaran yang ingin dicapai organisasi dapat disusun dengan baik.

Kejelasan sasaran anggaran merupakan sejauhmana tujuan anggaran ditetapkan secara jelas dan spesifik dengan tujuan agar anggaran tersebut dapat dimengerti oleh orang yang bertanggung jawab atas pencapaian sasaran anggaran tersebut (Kenis,1979) dalam (Hidayat, 2015). Oleh sebab itu sasaran anggaran pemerintah desa harus dinyatakan secara jelas, spesifik dan dapat dimengerti oleh mereka yang bertanggung jawab untuk melaksanakannya. Locke (1968) dalam Kenis (1979) menyatakan bahwa penetapan tujuan spesifik akan lebih produktif. Hal ini akan mendorong karyawan/staf untuk melakukan yang terbaik bagi pencapaian tujuan yang dikehendaki sehingga berimplikasi pada akuntabilitas pengelolaan dana desa. 
Akuntabilitas dipengaruhi oleh pengetahuan aparatur desa mengenai sistem pelaporan yang baik sehingga dapat memantau dan mengendalikan kinerja dalam mengimplementasikan anggaran yang telah ditetapkan. Pemerintah sebagai pengelola keuangan memiliki kewajiban untuk menyampaikan informasi keuangan dan informasi lainnya yang akan digunakan untuk pengambilan keputusan ekonomi dan sosial secara transparan dan akuntabel.

Sistem pelaporan merupakan laporan yang menggambarkan sistem pertanggungjawaban dari bawahan kepada atasan. Sistem pelaporan yang baik diperlukan agar dapat memantau dan mengendalikan kinerja manajer dalam mengimplementasikan anggaran yang telah ditetapkan. Pemerintah selaku pengelola dana publik harus mampu menyediakan informasi keuangan yang disajikan secara akurat, relevan, konsisten dan dapat dipercaya. Lembaga Administrasi Negara dan Badan Pengawas Keuangan dan Pembangunan BPKP mengemukakan laporan keuangan yang baik adalah laporan yang disusun secara objektif, jujur dan trasparan. Laporan umpan balik diperlukan untuk mengukur aktivitas-aktivitas yang dilaksanakan dalam rangka meningkatkan kinerja dan akuntabilitas pada pelaksanaan suatu rencana atau waktu mengimplementasikan suatu anggaran, sehingga manajemen dapat mengetahui hasil dari pelaksanaan rencana atau pencapaian sasaran anggaran yang telah ditetapkan.

Partisipasi masyarakat merupakan salah satu faktor yang mempengaruhi keberhasilan dari program pembangunan maupun pengembangan masyarakat pedesaan termasuk akuntabilitas pengelolaan dana desa. Diperlukan analisis mengenai partisipasi masyarakat dalam program pemberdayaan serta kondisi 
I Made Agus Suma Arta dan Ni Ketut Rasmini. Pengaruh...

partisipasi masyarakat dan faktor yang mempengaruhinya agar program pemberdayaan masyarakat dapat berkelanjutan.

Partisipasi masyarakat bukan hanya melibatkan masyarakat dalam pembuatan keputusan di setiap program pembangunan, namun masyarakat juga dilibatkan dalam mengidentifikasi masalah dan pontesi yang ada di masyarakat. Tanpa partisipasi masyarakat setiap kegiatan pembangunan akan gagal. Apapun bentuknya, partisipasi bertujuan untuk meningkatkan kemampuan setiap orang yang terlibat langsung maupun tidak langsung dalam sebuah pembangunan dengan cara melibatkan rekan dalam pengambilan keputusan dan pengawasan dalam kegiatan-kegiatan selanjutnya.

Partisipasi merupakan keikutsertaan masyarakat secara aktif dalam segala proses pembangunan baik dari sisi perencanaan, pengambilan keputusan, pelaksanaan dan evaluasi kegiatan dan merupakan urutan tertinggi dari suatu keterlibatan publik (Steffek, J, 2008) dalam (Riska, 2014). Partisipasi masyarakat adalah suatu proses ketika masyarakat, sebagai individu maupun kelompok sosial dan organisasi mengambil peran dalam proses perencanaan, pelaksanaan dan pemantauan pada kebijakan-kebijakan yang langsung mempengaruhi kehidupan mereka (Syamsi, 2015).

Partisipasi masyarakat adalah prinsip bahwa setiap orang memiliki hak untuk terlibat dalam pengambilan keputusan di setiap kegiatan penyelenggaraan pemerintahan yang dimulai dari perencanaan, pelaksanaan, penerimaan dan pemanfaatan hasil serta kesempatan untuk melakukan pengawasan pada kinerja aparatur desa (Amalia, 2017). Dobell dan Ulrich (2002) dalam (Oktasari, 2016) 
menyatakan bahwa ada tiga peran penting parlemen dalam proses anggaran yaitu mewakili kepentingan masyarakat, memberdayakan pemerintah dan mengawasi kinerja pemerintah. Salah satu efek positif adanya partisipasi masyarakat adalah pertukaran informasi yang efektif. Untuk menciptakan akuntabilitas kepada publik diperlukan partisipasi pimpinan instansi dan warga masyarakat dalam penyusunan dan pengawasan anggaran.

Berdasarkan Peraturan Pemerintah No. 71 Tahun 2010, anggaran merupakan pedoman tindakan yang akan dilaksanakan pemerintah meliputi rencana pendapatan, belanja transfer dan pembiayan yang diukur dalam satuan rupiah yang disusun menurut klasifikasi tertentu secara sistematis untuk satu periode. Maka dari itu diperlukan kejelasan sasaran anggaran. Kejelasan sasaran anggaran merupakan sejauhmana tujuan anggaran ditetapkan secara jelas dan spesifik dengan tujuan agar anggaran tersebut dapat dimengerti oleh orang yang bertanggungjawab atas pencapaian sasaran anggaran tersebut. Oleh sebab itu sasaran anggaran pemerintah daerah harus dinyatakan secara jelas, spesifik dan dapat dimengerti oleh mereka yang bertanggungjawab untuk melaksanakannya. Hasil penelitian Hidayattullah (2015) menunjukkan bahwa kejelasan sasaran anggaran berpengaruh positif signifikan pada akuntabilitas kinerja instansi pemerintah. Dengan adanya sasaran anggaran yang jelas maka akan mempermudah untuk mempertanggungjawabkan keberhasilan atau kegagalan pelaksanaan tugas organisasi. Hasil penelitian Hidayat (2015) menunjukkan bahwa kejelasan sasaran anggaran berpengaruh signifikan pada kinerja manajerial. Hasil penelitian Ali (2015) menunjukkan bahwa kejelasan sasaran anggaran 
I Made Agus Suma Arta dan Ni Ketut Rasmini. Pengaruh...

berpengaruh signifikan pada akuntabilitas kinerja instansi pemerintahan. Dalam penelitian Judarmita (2017) menunjukkan bahwa kejelasan sasaran anggaran berpengaruh positif pada akuntabilitas pengelolaan dana desa.

Berdasarkan uraian di atas, maka hipotesis yang diajukan dalam penelitian ini adalah sebagai berikut:

$\mathrm{H}_{1}$ : Kejelasan sasaran anggaran berpengaruh pada akuntabilitas pengelolaan dana desa

Berdasarkan pada teori Good Goverment Governance dalam lingkungan pemerintah akan membuat pemerintahan semakin baik dalam menjalankan setiap kegiatan yang ingin dilakukannya. Good Goverment Government adalah proses penciptaan lingkungan atau atmosfir kelembagaan yang memungkinkan adanya interaksi antar strata pemerintah dan rakyatnya dalam suatu tata nilai yang baik dan disepakati bersama. Maka perlunya sistem pelaporan yang dapat mencerminkan tata kelola pemerintahan yang baik. Sistem pelaporan merupakan laporan yang menggambarkan sistem pertanggungjawaban dari bawahan kepada atasan. Sistem pelaporan yang baik diperlukan agar dapat memantau dan mengendalikan kinerja manajerial dalam mengimplementasikan anggaran yang telah ditetapkan. Sistem pelaporan dalam sektor publik haruslah berpedoman pada standar akuntansi pemerintahan (SAP) dimana telah diatur dengan peraturanpemerintah No. 71 tahun 2010. Prosedur pencatatan menurut PP No. 71 Tahun 2010 tentang standar akuntansi pemerintah meliputi, pencatatan, penggolongan dan pengitisaran serta pelaporan. Pelaporan dalam pemerintahan sesuai PP No. 71 Tahun 2010 haruslah memuat laporan realisasi anggaran, neraca, laporan arus kas dan catatan atas laporan keuangan. 
Hasil penelitian Hidayattullah (2015) menyatakan bahwa sistem pelaporan berpengaruh signifikan pada akuntabilitas kinerja SKPD. Dalam penelitiaan Ali (2015) menyatakan bahwa sistem pelaporan berpengaruh pada akuntabilitas kinerja. Penelitian Cahyani (2015) menyatakan bahwa Sistem Pelaporan berpengaruh signifikan pada Akuntabilitas Kinerja. Dalam penelitian Judarmita (2017) Sistem Pelaporan berpengaruh positif dan signifikan pada Akuntabilitas Pengelolaan Dana Desa.

Berdasarkan uraian di atas, maka hipotesis yang diajukan dalam penelitian ini adalah sebagai berikut:

$\mathrm{H}_{2}$ : Sistem pelaporan berpengaruh pada akuntabilitas pengelolaan dana desa

Partisipasi masyarakat dalam pengelolaan dana desa sudah diatur dalam Undang-undang No. 6 tahun 2014 pada pasal 54 tentang musyawarah desa. Musyawarah desa merupakan forum permusyawaratan yang diikuti oleh badan permusyawaratan desa, pemerintah desa dan unsur masyarakat desa untuk memusyawaratkan hal yang bersifat strategis dalam penyelenggaraan pemerintahan desa yang meliputi penataan, perencanaan, kerjasama, rencana investasi yang masuk ke desa, pembentukan BUMDesa, penambahan dan pelepasan asset desa serta kejadian luar biasa. Partisipasi masyarakat adalah suatu proses ketika masyarakat, sebagai individu maupun kelompok sosial dan organisasi mengambil peran dalam proses perencanaan, pelaksanaan dan pemantauan pada kebijakan-kebijakan yang langsung mempengaruhi kehidupan mereka. Hasil penelitian Mada (2017) menyatakan bahwa partisipasi masyarakat berpengaruh positif dan signifikan pada akuntabilitas pengelolaan dana desa. Dengan adanya partisipasi masyarakat yang sering pada kegiatan di desa, maka 
I Made Agus Suma Arta dan Ni Ketut Rasmini. Pengaruh...

controlling pada penyimpangan-penyimpangan dapat diminimalisir. Dalam penelitian Mahayani (2017) menyatakan bahwa partisipasi masyarakat berpengaruh positif pada akuntabilitas pengelolaan dana desa.

Berdasarkan uraian di atas, maka hipotesis yang diajukan dalam penelitian ini adalah sebagai berikut:

$\mathrm{H}_{3}$ : Partisipasi masyarakat berpengaruh pada akuntabilitas pengelolaan dana desa.

\section{METODE PENELITIAN}

Populasi dalam penelitian ini adalah seluruh perangkat desa yang terlibat dalam pengelolaan dana desa yaitu mulai dari kepala desa, bendahara desa, sekretaris desa dan kepala seksi. Jadi banyaknya populasi dari 20 desa yang berada di Kecamatan Seririt adalah sebanyak 80 responden. Berdasarkan penelitian ini karena jumlah populasinya tidak lebih besar 100 orang responden, maka populasi yang diambil adalah keseluruhan populasi yang ada pada Kecamatan Seririt yaitu sebanyak 80 responden. Jadi metode pengambilan sampel menggunakan sampel jenuh.

Dalam menganalisis hipotesis dalam penelitian ini, metode analisis data yang digunakan adalah Analisis Regresi Berganda. Dalam uji hipotesis penelitian ini terdapat persamaan sebagai berikut:

$$
\mathrm{Y}=\alpha+\beta_{1} \mathrm{X}_{1}+\beta_{2} \mathrm{X}_{2}+\beta_{3} \mathrm{X}_{3}+\varepsilon
$$

Keterangan dari persamaan di atas adalah sebagai berikut:

$\mathrm{Y}=$ Akuntabilitas Pengelolaan Dana Desa

$\mathrm{X}_{1} \quad=$ Kejelasan Sasaran Anggaran

$\mathrm{X}_{2}=$ Sistem Pelaporan

$\mathrm{X}_{3}=$ Partisipasi Masyarakat

$\alpha=$ Konstanta 
$\beta_{1}-\beta_{3}=$ Koefisien regresi yang menunjukan angka peningkatan atau penurunan variabel dependen berdasarkan pada variabel independen

$\varepsilon=$ Error

\section{HASIL DAN PEMBAHASAN}

Statistik deskriptif dalam penelitian ini digunakan untuk memberikan informasi mengenai karakteristik variabel-variabel penelitian, antara lain nilai minimum, maksimum, rata-rata, simpangan baku (standar deviasi) dengan $\mathrm{N}$ adalah banyaknya responden penelitian disajikan dalam tabel 3 .

Tabel 3.

Hasil Uji Statistik Deskriptif

\begin{tabular}{lccccc}
\hline \multicolumn{1}{c}{ Variabel } & N & Minimum & Maximum & Mean & Std. Deviation \\
\hline Kejelasan Sasaran Anggaran & 80 & 18,00 & 24,00 & 20,36 & 3,53 \\
Sistem Pelaporan & 80 & 15,00 & 20,00 & 17,19 & 2,51 \\
Partisipasi Masyarakat & 80 & 42,00 & 56,00 & 49,09 & 15,47 \\
Akuntabilitas Pengelolaan Dana Desa & 80 & 30,00 & 40,00 & 34,98 & 10,53 \\
\hline
\end{tabular}

Sumber: Data diolah, 2018

Penjabaran dari hasil uji statistik deskriptif pada Tabel 3 bahwa variabel kejelasan sasaran anggaran memiliki nilai minimum sebebsar 18,00 dan nilai maksimum sebesar 24,00. Nilai rata-rata untuk variabel kejelasan sasaran anggaran adalah 20,36 dengan penyimpangan sebesar 3,53.

Variabel sistem pelaporan memiliki nilai minimum sebesar 15,00 dan nilai maksimum sebasar 20,00. Nilai rata-rata untuk variabel sistem pelaporan adalah 17,19 dengan nilai penyimpangan 2,51.

Variabel partisipasi masyarakat memiliki nilai minimum sebesar 42,00 dan nilai minimum sebesar 56,00. Nilai rata-rata untuk variabel sistem pelaporan adalah 49,09 dengan nilai penyimpangan 15,47. 
I Made Agus Suma Arta dan Ni Ketut Rasmini. Pengaruh...

Variabel Akuntabillitas Pengelolaan Dana Desa memiliki nilai minimum sebesar 30,00 dan nilai maksimum sebesar 40,00. Nilai rata-rata untuk variabel sistem pelaporan adalah 34,98 dengan nilai penyimpangan 10,53 .

Perhitungan koefisien regresi linier berganda dilakukan dengan analisis regresi melalui software SPSS 21 for Windows, diperoleh hasil yang ditunjukan pada Tabel 4 .

Tabel 4.

Hasil Analisis Regresi Linier Berganda

\begin{tabular}{lcccc}
\hline \multicolumn{1}{c}{ Variabel } & Unstandardized Beta & Std. Error & T hitung & Sig. uji t \\
\hline Constant & 3,340 & 5,812 & 0,575 & 0,567 \\
Kejelasan Sasaran Anggaran $\left(\mathrm{X}_{1}\right)$ & 0,703 & 0,168 & 4,181 & 0,000 \\
Sistem Pelaporan $\left(\mathrm{X}_{2}\right)$ & 0,465 & 0,199 & 2,333 & 0,022 \\
Partisipasi Masyarakat $\left(\mathrm{X}_{3}\right)$ & 0,190 & 0,079 & 2,411 & 0,018 \\
\hline Ajusted $R$ Square & 0,281 & & & \\
F & 11,309 & & & \\
Sig. & $0,000^{\mathrm{b}}$ & & & \\
\hline
\end{tabular}

Sumber: Data diolah, 2018

Berdasarkan hasil analisis regresi linier berganda seperti yang disajikan pada Tabel 4, maka dapat dibuat persamaan regresi sebagai berikut.

$$
Y=3,340+0,703 X_{1}+0,465 X_{2}+0,190 X_{3}+\varepsilon
$$

Nilai konstanta $(\alpha)$ menunjukkan besarnya nilai variabel dependen apabila variabel independen adalah 0 (nol). Nilai konstata sebesar 3,340 menujukkan besarnya akuntabilitas pengelolaan dana desa adalah sebesar 3,340 apabila kejelasan sasaran anggaran, sistem pelaporan dan partisipasi masyarakat adalah 0 (nol) dengan nilai signifikasinya $<0,05$.

Nilai koefisien kejelasan sasaran anggaran $\left(\mathrm{X}_{1}\right)$ 0,703 menunjukkan bila kejelasan sasaran anggaran $\left(\mathrm{X}_{1}\right)$ bertambah sebesar 1 satuan maka nilai dari akuntabilitas pengelolaan dana desa (Y) akan mengalami kenaikan sebesar 0,703 satuan dengan asumsi variabel bebas lainnya konstan. 
Nilai koefesien sistem pelaporan $\left(\mathrm{X}_{2}\right)$ 0,465 menunjukkan bila sistem pelaporan $\left(\mathrm{X}_{2}\right)$ bertambah sebesar 1 satuan maka nilai dari akuntabilitas pengelolaan dana desa (Y) akan mengalami kenaikan sebesar 0,465 satuan dengan asumsi variabel bebas lainnya konstan.

Nilai koefesien partisipasi masyarakat $\left(\mathrm{X}_{3}\right)$ 0,190 menunjukkan bila partisipasi masyarakat $\left(\mathrm{X}_{3}\right)$ bertambah sebesar 1 satuan maka nilai dari akuntabilitas pengelolaan dana desa (Y) akan mengalami kenaikan sebesar 0,190 satuan dengan asumsi variabel bebas lainnya konstan.

Dalam penelitian ini apabila hasil dari Uji F menyatakan signifikan $\mathrm{F}$ atau $\mathrm{P}$ value $<0,05$ maka hubungan antar variabel-variabel bebas adalah signifikan memengaruhi akuntabilitas pengelolaan dana desa di Kecamatan Seririt Kabupaten Buleleng dan model regresi yang digunakan dianggap layak uji. Hasil uji simultan/uji $\mathrm{F}$ akan disajikan pada Tabel 4. Dapat dilihat bahwa nilai signifikasi uji $\mathrm{F}$ yaitu sebesar 0,000 lebih kecil dari 5\% $(0,000<0,05)$. Hal ini berarti variabel bebas berpengaruh secara serempak pada variabel terikat pada tingkat signifikasi $5 \%$.

Koefesien determinasi mengukur seberapa jauh kemampuan variasi variabel independen dalam menerangkan variansi variabel dependen. Pada penelitian ini, koefisien determinasi yang digunakan adalah nilai dari adjusted $R^{2}$ karena apabila suatu variabel ditamah ke model dan hasilnya tidak signifikan, maka akan mengalami kenaikan yang tidak terlalu tinggi. Hasil uji koefisien determinasi disajikan pada Tabel 4 . 
I Made Agus Suma Arta dan Ni Ketut Rasmini. Pengaruh...

Berdasarkan Tabel 4 dapat diketahui nilai dari Adjusted $R$ Square adalah 0,281 atau $28,1 \%$, ini artinya variasi akuntabilitas pegelolaan dana desa dipengaruhi oleh kejelasan sasaran anggaran, sistem pelaporan dan partisipasi masyarakat. Sisanya sebesar $72,9 \%$ dijelaskan oleh variabel-variabel yang tidak dijelaskan dalam penelitian ini.

Di dalam penelitian ini Uji t dilakukan untuk menunjukkna pengaruh semua variabel-variabel independen secara parsial pada variabel dependen. Pengaruh kejelasan sasaran anggaran, sistem pelaporan, dan partisipasi masyarakat pada akuntabilitas pengelolaan dana desa dapat dilihat dengan membandingkan nilai probabilitas dengan level of significance $(\alpha)$ sebesar 5\%. Penarikan kesimpulan dilakukan dengan kriteria apabila probabilitas < level of significance 5\%, maka kejelasan sasaran anggaran, sistem pelaporan dan partisipasi masyarakat secara parsial berpengaruh pada akuntabilitas pengeloaan dana desa $\left(\mathrm{H}_{0}\right.$ ditolak dan $\mathrm{H}_{1}$ diterima). Sebaliknya, apabila nilai probabilitas > level of significance 5\%, maka kejelasan sasaran anggaran, sistem pelaporan dan partisipasi masyarakat secara parsial tidak berpengaruh pada akuntabilitas pengelolaan dana desa $\left(\mathrm{H}_{0}\right.$ diterima dan dan $\mathrm{H}_{1}$ ditolak). Hasil uji t disajikan pada Tabel 4.

Berdasarkan hasil analisis Tabel 4 menunjukkan bahwa kejelasan sasaran anggaran memiliki nilai signifikansi sebesar 0,000 dengan nilai $t_{\text {hitung }}$ sebesar 4,181. Nilai signifikansi 0,000 lebih kecil dari tingkat kesalahan yang dapat diterima yaitu $5 \%$ atau $0,05(0,000<0,05)$ mengindikasikan bahwa $\mathrm{H}_{0}$ ditolak dan $\mathrm{H}_{1}$ diterima. Hal ini menunjukkan bahwa semakin jelas kejelasan sasaran 
anggaran yang ada di pemerintahan desa, maka akuntabilitas pengelolaan dana desa akan semakin meningkat.

Berdasarkan hasil analisis Tabel 4 menunjukkan bahwa sistem pelaporan memiliki nilai signifikansi sebesar 0,022 dengan nilai $t_{\text {hitung }}$ sebesar 2,333 . Nilai signifikansi 0,022 lebih kecil dari tingkat kesalahan yang dapat diterima yaitu 5\% atau $0,05(0,022<0,05)$ mengidikasikan bahwa $\mathrm{H}_{0}$ ditolak dan $\mathrm{H} 2$ diterima. Hal ini menunjukkan bahwa semakin bagus sistem pelaporan di pemerintahan desa maka akuntabilitas pengelolaan dana desa akan semakin bagus.

Berdasarkan hasil analisis Tabel 4 menunjukkan bahwa partisipasi masyarakat memiliki nilai signifikansi 0,018 dengan nilai $t_{\text {hitung }} 2,411$. Nilai signifikansi 0,018 lebih kecil dari tingkat kesalahan yang dapat diterima yaitu 5\% atau $0,05(0,018<0,05)$ mengindikasikan bahwa $\mathrm{H}_{0}$ ditolak dan $\mathrm{H}_{3}$ diterima. Hal ini menunjukkan bahwa semakin tinggi partisipasi masyarakat dalam pemerintahan desa, maka akuntabilitas pengelolaan dana desa akan semakin meningkat.

Hipotesis pertama pada penelitian ini menyatakan bahwa kejelasan sasaran anggaran berpengaruh positif pada akuntabilitas pengelolaan dana desa di Kecamatan Seririt Kabupaten Buleleng. hasil pengujian dengan menggunakan regresi linier berganda sejalan dengan hipotesis yang dirumuskan yang menunjukkan bahwa kejelasan sasaran anggaran berpengaruh positif pada akuntabilitas pengelolaan dana desa. Nilai regresi menunjukkan nilai korfesien positif sebesar 0,703 dengan nilai signifikansi sebesar 0,000 yang lebih kecil dari $0,05(0,000<0,05)$. Nilai koefesien regresi positif menunjukkan hubungan yang 
I Made Agus Suma Arta dan Ni Ketut Rasmini. Pengaruh...

searah antara kejelasan sasaran anggaran dengan akuntabilitas pengelolaan dana desa. Hasil ini memiliki arti bahwa semakin baik kejelasan sasaran anggaran dalam pemerintahan desa maka akuntabilitas pengelolaan dana desa akan semakin meningkat.

Hasil ini mendukung theory agency terkait dengan kejelasan sasaran anggaran pada akuntabilitas pengelolaan dana desa. Semakin jelas anggaran dalam pemerintahan desa akan meningkatkan akuntabilitas pengelolaan dana desa. Hal ini sejalan dengan hasil penelitian Hidayatullah (2015), Hidayat (2015), Ali (2015) dan Judaemita (2017) yang menyatakan bahwa kejelasan sasaran anggaran berpengaruh positif pada akuntabilitas pengelolaan dana desa.

Disamping itu berdasarkan jawaban dari kuesioner yang disebar, dapat diketahui bahwa dalam variabel kejelasan sasaran anggaran mayoritas responden menjawab anggaran dalam APBDesa yang dibuat telah mempertimbangkan sekala prioritas. Jadi dana desa yang diberikan oleh pemerintah pusat sudah dapat digunakan sesuai dengan kebutuhan masyarakat.

Hipotesis kedua pada penelitian ini menyatakan bahwa sistem pelaporan berpengaruh posistif pada akuntabilitas pengelolaan dana desa di Kecamatan Seririt Kabupaten Buleleng. hasil pengujian dengan menggunakan regresi linier berganda sejalan dengan hipotesis yang dirumuskan yang menunjukkan bahwa sistem pelaporan berpengaruh positif pada akuntabilitas pengelolaan dana desa. Nilai regresi menunjukkan nilai koefesien positif sebesar 0,465 dengan nilai signifikansi sebesar 0,022 yang lebih kecil dari $0,05(0,022<0,05)$. Nilai 
koefisien regresi positif menunjukkan hubungan yang searah antara sistem pelaporan dengan akuntabilitas pengelolaan dana desa.

Hasil ini mendukung theory agency terkait dengan sistem pelaporan yang dibuat oleh agen (kepala desa besarta staff desa) yang menunjukkan akuntabilitas dalam mengelola dana desa. Semakin baik sistem pelaporan salam pemerintah desa akan meningkatkan akuntabilitas pengelolaan dana desa. . Hal ini sejalan dengan hasil penelitian Hidayatullah (2015), Ali (2015), Cahyani (2015) dan Judarmita (2017) yang menyatakan bahwa sistem pelaporan berpengaruh positif dan signifikan pada akuntabilitas pengelolaan dana desa.

Disamping itu berdasarkan jawaban kuesioner yang telah disebarkan sistem pelaporan di Desa sangat berpedoman terhadap Permendagri No. 113 Tahun 2014 dalam hal pengelolaan keuangan desa. Sehingga dana desa dapat dipertanggungjawabkan dengan baik dan dapat berguna bagi masyarakat desa itu sendiri.

Hipotesis ketiga dalam penelitian ini menyatakan bahwa partisipasi masyarakat berpengaruh positif pada akuntabilitas pengelolaan dana desa di Kecamatan Seririt Kabupaten Buleleng. Hasil pengujian dengan menggunakan regresi linier berganda sejalan dengan hipotesis yang dirumuskan yang menunjukkan bahwa partisipasi masyarakat berpengaruh positif pada akuntabilitas pengelolaan dana desa. Nilai regresi menunjukkan nilai koefisien positif sebesar 0,190 dengan nilai signifikansi sebesar 0,018 yang lebih kecil dari $0,05(0,018<$ 0,05). Nilai koefisien regresi positif menunjukkan hubungan searah antara partisipasi masyarakat dengan akuntabilitas pengelolaan dana desa. 
I Made Agus Suma Arta dan Ni Ketut Rasmini. Pengaruh...

Hal ini sesuai dengan theory agency bahwa partisipasi masyarakat merupakan salah satu penilaian principal pada kinerja dari agent. Hasil penelitian ini sejalan dengan penelitian sebelumnya yang dilakukan oleh Mada (2017) dan Mahayani (2017) yang menyatakan bahwa partisipasi masyarakat berpengaruh positif pada akuntabilitas pengelolaan dana desa.

Disamping itu, berdasarkan jawaban kuesioner yang telah disebarkan mayoritas responden menilai saran dan kritik dari masyarakat dijadikan pertimbangan untuk merevisi anggaran dalam pemerintahan desa. Jadi ini merupakan salah satu peran penting dalam mengewasi dan memantau dana desa, supaya dana tersebut benar-benar telah digunakan dengan sebaik-baiknya dan sesuai dengan kebutuhan dari masyarakat.

Penelitian ini menghasilkan simpulan mengenai pengaruh kejelasan sasaran anggaran, sistem pelaporan dan partisipasi masyarkat pada akuntabilitas pengelolaan dana desa di Kecamatan Seririt Kabupaten Buleleng. Hasil uji dalam penelitian ini menemukan bahwa varibel independen yaitu kejelasan sasaran anggaran, sistem pelaporan dan partisipasi masyarkat berpengaruh positif pada variabel dependen yaitu akuntabilitas pengelolaan dana desa.

Penelitian ini mendukung theory agency yaitu kontrak kerja antara manjemen (agent) dengan investor (principal) dalam pemerintah desa, kepala desa sebagai agent dan masyarakat sebagai principal. Penelitian ini juga mendukung teori good government governance dimana dalam penciptaan tata kelola pemerintahan yang baik antar strata pemerintahan dan antara pemerintah dengan rakyatnya. 
Penelitian ini dapat digunakan sebagai motivasi bagi pemerintah desa untuk dapat membuat anggaran dalam pemerintahan menjadi semakin jelas, sistem pelaporan sesuai dengan regulasi yang berlaku dalam pemerintahan desa. Selain itu penelitian ini dapat digunakan sebagai wawasan dan motivasi kepada masyarakat untuk melakukan pengawasan pada penggunaan dana desa.

\section{SIMPULAN}

Penelitian ini menguji pengaruh kejelasan sasaran anggaran, sistem pelaporan, dan partisipasi masyarakat pada akuntabilitas pengelolaan dana desa. Lokasi penelitian ini dilakukan di Kecamatan Seririt Kabupaten Buleleng dengan mengambil 20 desa sebagai sampel dari 20 desa yang ada di Kecamatan Seririt. Berdasarkan hasil dan pembahasan, simpulan ini dapat diuraikan sebagai berikut.

Kejelasan sasaran anggaran berpengaruh positif pada akuntabilitas pengelolaan dana desa di Kecamatan Seririt Kabupaten Buleleng. Hal ini berarti semakin jelas anggaran dalam pemerintahan desa maka semakin tinggi akuntabilitas pengelolaan dana desa.

Sistem pelaporan berpengaruh positif pada akuntabilitas pengelolaan dana desa di Kecamatan Seririt Kabupaten Buleleng. Hal ini berarti semakin baik sistem pelaporan dalam pemerintahan desa maka akan meningkatkan akuntabilitas pengelolaan dana desa.

Partisipasi masyarakat berpengaruh positif pada akuntabilitas pengelolaan dana desa di Kecamatan Seririt Kabupaten Buleleng. Hal ini berarti semakin aktif masyarakat dalam mengawasi penggunaan dana desa akan meningkatkan akuntabilitas pengelolaan dana desa 
Berdasarkan hasil jawaban kuesioner yang telah disebarkan, perlu ada beberapa hal yang harus ditingkatkan oleh pemerintah desa. Dari segi kejelasan sasaran anggaran perangkat desa yang terlibat dalam pengelolaan keuangan desa harus mengetahui secara jelas outcome yang harus dicapai pada setiap program dan kegiatan yang dilaksanakan di desa. Kemudian dalam sistem pelaporan pemerintah desa harus memperhatikan penggunaan anggaran supaya sisa anggaran (SiLPA) tidak lebih besar dari 30\%. Dari segi partisipasi masyarakat perlu ditingkatkan lagi partisipasi masyarakat dalam advokasi anggaran, perancangan anggaran dan pelaksanaan APBDesa. Selain itu, penelitian selanjutnya diharapkan untuk menggunakan sampel desa yang ada di Kabupaten Buleleng agar diperoleh hasil penelitian dengan tingkat generalisasi yang lebih tinggi. Koefisien determinasi (Adjusted $R^{2}$ ) adalah sebesar 0,281 yang berarti variabilitas variabel dependen yang dapat dijelaskan oleh variabel independen hanya sebesar $28,1 \%$, sedangkan sisanya sebesar $71,9 \%$ dijelaskan oleh variabel lain di luar model penelitian. Penelitian selanjutnya dapat menambahkan variabel lain seperti audit kinerja yang dapat mempengaruhi akuntabilitas pengelolaan dana desa. Hal ini diperuntukkan agar hasil dari penelitian berikutnya dapat digunakan secara lebih luas.

\section{REFERENSI}

Ali, Z. 2015. Kejelasan Sasaran Anggaran, Pengendalian Akuntansi, Sistem Pelaporan Dan Akuntabilitas Kinerja Instansi Pemerintah Pada Inspektorat Jenderal Kementerian Agama Ri. Jurnal Riset Akuntansi dan Perpajakan JRAP, 2(1), hal.89-96.

Amalia, R. 2017. Pengaruh Trasnparansi, Akuntabilitas Dan Partisipasi Masyarakat Dalam Pengelolaan Keuangan Desa Pada Pembangunan Desa. 
Skripsi Sarjana Jurusan Akuntansi pada Fakultas Ekonomi dan Bisnis Universitas Lampung, Bandar Lampung.

Aucoin, P., \& Heintman, R. 2000. The Dialectics of Accountability for Performance in Public Management Reform. International Review of Administrative Sciences, 66(1). 45-55.

Astuty, E. H. F. 2013. Akuntabilitas Pemerintah Desa Dalam Pengelolaan Anggaran Pendapatan Dan Belanja Desa (Apbdes) (Studi Pada Alokasi Dana Desa Tahun Anggaran 2011 Di Desa Sareng Kecamatan Geger Kabupaten Madiun). Publika, 1(2).

Cahyani, M. 2015. Pengaruh Kejelasan Sasaran Anggaran, Pengendalian Akuntansi Dan Sistem Pelaporan Pada Akuntabilitas Kinerja. E-Jurnal Akuntansi Universitas Udayana, 3(8), 663-676.

Dobell, Peter and Ulrich. 2003, Parliament's performance in thr budget process: A case study. Policy Matters, 3(2): 1-14.

Hidayat, T. 2015. Pengaruh Kejelasan Sasaran Anggaran, Struktur Desentralisasi Dan Locus Of Control Pada Kinerja Manajerial. E-Jurnal UIN Syarif Hidayatullah Jakarta, 8(2), hal.148-161.

Hidayattullah, A, I. H. 2015. Pengaruh Kejelasan Sasaran Anggaran, Pengendalian Akuntansi, Sistem Pelaporan Pada Akuntabilitas Kinerja Skpd Di Merauke, hal.978-979.

Judarmita, N. 2017. Pengaruh Kejelasan Sasaran Anggaran, Sistem Pelaporan Dan Audit Kinerja Pada Akuntabilitas Pengelolaan Dana Desa. E-Jurnal Akuntansi Universitas Udayana, 21, hal.1719-1746.

Kenis, I. 1979. Effect on Budgetary Goal Characteristic on Managerial Attitudes and Performance. The Accounting Review, Vol. LIV, No. 4, pp: 707.

Kluvers, R. 2011. The Views of Councillors and Managers on Accountability in Local Governmenr: An Emprical Study in Austraia.

Mada, S. 2017. Pengaruh Kompetensi Aparat Pengelola Dana Desa , Komitmen Organisasi Pemerintah Desa, Dan Partisipasi Masyarakat Pada Akuntabilitas Pengelolaan Dana Desa Di Kabupaten Gorontalo. Jurnal Riset Akuntansi Dan Auditing, 8, hal.106-115.

Mahayani, N.L.A. 2017. Prosocial Behavior Dan Persepsi Akuntabilitas Pengelolaan Dana Desa Dalam Konteks Budaya Tri Hita Karana. Jurnal Ilmiah Akuntansi dan Bisnin Universitas Uudayana, hal.129-144. 
Mulgan, R. 2000. Accountability: An Ever-Expanding Concept? Journal Public Administration, 78(3), 555-576.

Oktasari, R. 2016. Pengaruh Akuntabilitas Publik, Partisipasi Masyarakat, Transparansi Kebijakan Publik, Dan Pengetahuan Dewan Tentang Anggaran Pada Pengawasan Keuangan Daerah (Apbd) Di Dprd Kabupaten Karanganyar. Universitas Muhammadiyah Surakarta, hal.1-18.

Patton, J.M. 1992. Accountability and Govermental Financial Reporting, Journal of Financial Accountability and Management Autumn, 150-165.

Randa, F. 2014. Memahami Dimensi Akuntabilitas Pada Organisasi Pemerintah Daerah (Studi Etnografi Pada Pemerintah Daerah Tingkat Ii Tana Toraja).

Riska, W. 2014. Analisis Partisipasi Masyarakat Dan Kepemimpinan Pada Tingkat Keberhasilan Proyek Program Nasional Pemberdayaan Masyarakat (Pnpm) Mandiri Perdesaan Di Kecamatan Gerokgak, Buleleng-Bali. Jurnal Bisnis Studi Ekonomi Universitas Udayana, hal. 175-183.

Scott, C. 2000. Accountability in The Regulatory State. Journal of Law and Society, 27(1), 38-60.

Suratmi, N. T. H. 2014. Pengaruh Audit Kinerja, Penyajian Laporan Keuangan, Dan Aksesibilitas Laporan Keuangan Pada Akuntabilitas Publik. E-Journal S1 Ak Universitas Pendidikan Ganesha Jurusan Akuntansiprogram S1, 2(1).

Steffek, Jens. 2008. Public Accountability and the Public Sphere of International Governance, Recon Online Working Paper 2008/03.

Syamsi, S. 2015. Partisipasi Masyarakat Dalam Mengontrol Penggunaan Anggaran Dana Desa. Fakultas Ilmu Sosial Dan Ilmu Politik, 3(1), hal.21-28.

Tribun-Bali. 2018. "Ratnadi Terima Divonis 2 Tahun, Terbukti Gelapkan Dana APBDesa Satra, Kelungkung $\mathrm{Rp} 94 \quad$ Juta". http://bali.tribunnews.com/2018/09/06/ratnadi-terima-divonis-2-tahunterbukti-gelapkan-dana-apbdes-desa-satra-klungkung-rp-94-juta. Diunduh tanggal 3 Desember 2018.

Undang-Undang Republik Indonesia Nomor 32 Tahun 2004 Tentang Pemerintahan Daerah.

Undang - Undang Republik Indonesia Nomor 6 Tahun 2014 Tentang Desa.

Undang-Undang Republik Indonesia Nomor 15 Tahun 2004 Tentang Pemeriksaan Pengelolaan Dan Tanggungjawab Keuangan Negara. 
ISSN: 2302-8556

E-Jurnal Akuntansi Universitas Udayana Vol.26.1.Januari (2019): 709-735

Undang-Undang Republik Indonesia Nomor 18 Tahun 2016 Tentang Anggaran Pendapatan dan Belanja Negara. 